\title{
Survey on selling trend of insecticides for insect pest management in vegetable crops at Raipur (Chhattisgarh)
}

\author{
Arvind Kumar Ayam* and V. K. Koshta
}

Department of Entomology, College of Agriculture, Indira Gandhi Agricultural University, Raipur (C.G.) India

\section{ARITCLE INFO}

Received : 19.12 .2017

Revised : 16.03 .2018

Accepted : 24.03.2018

\section{KEY WORDS :}

Insecticides, Peak period, Demand, Correlation, Constraints

*Corresponding author:

\begin{abstract}
The findings revealed that out of 50 respondents, majority of the 64.00 per cent were middle age group, 44.00 per cent belong to 5-10 years of experience and 64.00 per cent were graduated and 92.00 per cent shops operated by owner. Peak period of demand for insecticides was in Kharif season identified by 56.00 per cent respondents. Highest demand of insecticides for a particular vegetable observed by 28.00 per cent in cabbage. Majority $(80.00 \%)$ of the respondents dealing insecticides alongwith herbicide, fungicide, seed, micro- nutrients and farm implements and 45.00 per cent were well aware about banned/registered insecticides. Most demanded Chlorpyriphos and cypermethrin insecticides identified by 36.00 per cent and 26.00 per cent respondents. The co-efficient of correlation showed positive and highly significant with the business experience. Constraints faced during the sale reported were knowledge on the handle of expired material $(60 \%)$ and payments were not received by farmers at proper time $(54 \%)$.
\end{abstract}

How to view point the article : Ayam, Arvind Kumar and Koshta, V.K. (2018). Survey on selling trend of insecticides for insect pest management in vegetable crops at Raipur (Chhattisgarh). Internat. J. Plant Protec., 11(1) : 93-101, DOI : 10.15740/HAS/IJPP/11.1/93-101. 